\title{
RELATIONSHIP BETWEEN FUNCTIONAL TRAITS, FUNCTIONAL TYPES, AND HABITAT IN BOREONEMORAL BRYOPHYTES
}

\author{
Gederts levinsh", Laura Gaile, Didzis Elferts, and Ligita Liepiṇa \\ Faculty of Biology, University of Latvia, 1 Jelgavas Str., Rìga, LV-1004, LATVIA \\ \# Corresponding author, gederts.ievins@lu.Iv
}

Communicated by Gunta Sprinǵge

The aim of the present study was to determine a relationship between physiological traits and functional types of bryophytes from five boreonemoral habitats with a particular emphasis on discriminative ability of these traits. Sampling of 25 species was performed four times during one season. Water content, chlorophyll a fluorescence and photosynthetic pigment concentration were measured in field and water-equilibrated samples. Principal component analysis indicated the existence of an inverse relationship between concentration of pigments and water content. Linear discriminant analysis showed that relatively high mean predicted posterior probabilities of correct classification of functional types by physiological traits were found for water conducting system, followed by substrate and habitat, but it was highly variable and type-specific for life form and relatively less variable for life strategy. Field water content had the highest average discriminative importance among physiological traits, followed by chlorophyll fluorescence indices field $F_{V} / F_{m}$, equilibrated PI, equilibrated RC/ABS, and field RC/ABS. Photosynthetic pigment concentrations had relatively less average importance for classification of functional types.

Key words: chlorophyll, hlorophyll a fluorescence, life form, life strategy, pigments, substrate, water conducting system.

\section{INTRODUCTION}

In addition to classification by taxa, different functional types of plants have been described. For example, functional classifications have been used to predict changes in ecosystems due to global climate change (Lavorel et al., 2007). While no single and comprehensive system has been established for vascular plants, both life forms and life strategies have emerged as useful concepts in bryophyte ecology. Relationships between bryophyte life form and habitat have been frequently described since the early studies in bryophyte ecology (Gimingham and Birse, 1957). Life forms are often associated with adaptations to moisture availability and light intensity (Bates, 1998). It is generally accepted that short turfs and cushions are typical for sunny, dry and xeric habitats, while bryophytes forming mats, wefts, tails and fans dominate humid and shady habitats (Bates, 1998; Kürschner, 2004). Recently, life forms have been used to explain a 100-year-long succession of bryophytes in forest habitat, which was associated with increase of available substrates as well as habitat shading (Strazdina et al., 2013). In particular, these changes led to disappearance of compact cushions and short turfs, while smooth and rough mats increased in richness. Evidently, life forms are a reflection of adaptation to the environment.

In addition to life forms, bryophyte classification by life strategies is based mostly on reproduction and life span characteristics (During, 1979; Kürschner, 2004). Recently, distribution of mountain stream bryophytes with different life forms and life strategies in relation to water velocity, light incidence and hydrological zone has been described (Vieira et al., 2012). It is reasonable to suggest that both systems of functional classification of bryophytes, life forms and life strategies, are associated with specific morphophysiological adaptations to environmental conditions. However, physiological traits have not been frequently used for ecological classification. The only physiological trait used so far for functional classification was based on the water-conducting system: ectohydric (transporting water externally) and endohydric (having internal transport system (Glime, 2007b). However, a considerable number of species 
can exhibit both types of water conduction, in reality being myxohydric. In the context of the present paper, "functional types" are groupings of bryophyte species according to habitat, substrate, water conducting system, life form and life strategy. Functional classification systems of bryophytes are rather descriptive, without much experimentally based evidence. Therefore, it can be asked if groups of species with particular "functional type" represent reflections of different physiological adaptations?

Photosynthesis-related traits are widely used in ecophysiology of vascular plants to characterise their physiological state and responses to the environment (Albert et al., 2011). Among them, measurement of chlorophyll $a$ fluorescence is a non-destructive analytical method to estimate photochemical activity of plants (Baker, 2008). As photosystem II (PS II) is highly sensitive to both physiological state of a plant as well as changes in the environment, chlorophyll $a$ fluorescence measurements have been used in a multitude of studies (Murchie and Lawson, 2013). For bryophytes, this type of analysis has been used mostly in dehydration/rehydration experiments as an indication of the state of photosynthetic apparatus (Proctor, 2003; Beckett et al., 2005; Cruz de Carvalho et al., 2011). Recently, it has been shown that the fast chlorophyll $a$ fluorescence method can provide quantitative estimates of the photochemical activity of bryophytes with potential use in ecophysiological studies (Liepiña and Ievinsh, 2013). In addition, photosynthetic pigment concentration has been used as an indicator of photosynthetic activity in desiccation experiments (Martin and Warner, 1984) as well as in ecophysiology (Lopez and Carballeira, 1989), e.g., for characterisation of the relationship with light availability (Marschall and Proctor, 2004).

The aim of the present study was to determine whether or not water content and photosynthesis-related traits could be used as indicators for functional classification of bryophyte species. Water content-related as well as photosynthesisrelated traits, namely, photosynthetic pigment concentration and characteristics of PS II photochemical activity, were measured for 25 bryophyte species growing on different substrates from relatively similar boreonemoral habitats during a vegetation season. It was hypothesised that it is possible to define functional groups of bryophytes based on these physiological traits.

\section{MATERIALS AND METHODS}

Habitats and species. The study was conducted in five boreonemoral habitats located along a $35-\mathrm{km}$ transect in the $\mathrm{W}-\mathrm{E}$ direction in the central part of Latvia (Table 1). Habitat A was represented by a deciduous forest with Acer pla-

Table 1. Functional classification of studied bryophyte species

\begin{tabular}{|c|c|c|c|c|c|c|}
\hline Habitat & No & Species & Substrate & $\begin{array}{c}\text { Water conducting } \\
\text { system }\end{array}$ & Life form & Life strategy \\
\hline $\mathrm{A}$ & 1 & Brachythecium rutabulum & epiphytic & ectohydric & rough mat & pioneer \\
\hline A & 2 & Homalia trichomanoides & epiphytic & ectohydric & smooth mat & stress-tolerant perennial \\
\hline A & 3 & Leucodon sciuroides & epiphytic & ectohydric & tail & long-lived shuttle \\
\hline A & 4 & Ortotrichum affine & epiphytic & endohydric & small cushion & colonist \\
\hline A & 5 & Plagiomnium undulatum & epigeic & endohydric & dendroid & competitive perennial \\
\hline B & 6 & Hypnum cupressiforme & epiphytic & ectohydric & smooth mat & stress-tolerant perennial \\
\hline B & 7 & Hypnuт cupressiforme & epilytic & ectohydric & smooth mat & stress-tolerant perennial \\
\hline B & 8 & Anomodom longifolius & epilytic & ectohydric & tail & perennial stayer \\
\hline B & 9 & Cratoneuron filicinum & epilytic & ectohydric & weft & perennial stayer \\
\hline B & 10 & Conocephalum conicum & epigeic & endohydric & thalloid-mat & long-lived shuttle \\
\hline $\mathrm{C}$ & 11 & Climacium dendroides & epigeic & endohydric & dendroid & competitive perennial \\
\hline $\mathrm{C}$ & 13 & Atrichum undulatum & epigeic & endohydric & tall turf & short lived shuttle \\
\hline $\mathrm{C}$ & 14 & Calliergonella cuspidata & semi-aquatic & ectohydric & weft & competitive perennial \\
\hline $\mathrm{C}$ & 15 & Lophocolea heterophylla & epixylic & ectohydric & thread-like mat & pioneer \\
\hline $\mathrm{D}$ & 16 & Rhytidiadelphus triquetrus & epigeic & endohydric & weft & competitive perennial \\
\hline $\mathrm{D}$ & 17 & Ptilium crista-castrensis & epigeic & ectohydric & weft & perennial stayer \\
\hline $\mathrm{D}$ & 18 & Hylocomium splendens & epigeic & ectohydric & weft & competitive perennial \\
\hline $\mathrm{D}$ & 19 & Dicranum polysetum & epigeic & endohydric & tall turf & competitive perennial \\
\hline $\mathrm{D}$ & 20 & Pleurozium schreberi & epigeic & ectohydric & weft & competitive perennial \\
\hline $\mathrm{E}$ & 21 & Sphagnum russowii & epigeic & ectohydric & sphagnoid & long-lived shuttle \\
\hline $\mathrm{E}$ & 22 & Sphagnum riparium & aquatic & ectohydric & sphagnoid & long-lived shuttle \\
\hline $\mathrm{E}$ & 23 & Sphagnum magellanicum & semi-aquatic & ectohydric & sphagnoid & long-lived shuttle \\
\hline $\mathrm{E}$ & 24 & Sphagnum cuspidatum & aquatic & ectohydric & sphagnoid & long-lived shuttle \\
\hline
\end{tabular}

Habitats: A, deciduous forest, $56^{\circ} 48^{\prime} 8^{\prime} \mathrm{N}, 24^{\circ} 51^{\prime} 48^{\prime \prime} \mathrm{E}$; B, ravine with stream, 56 $47^{\prime} 54^{\prime \prime} \mathrm{N}, 2^{\circ} 52^{\prime} 0^{\prime \prime} \mathrm{E}$; C, mixed wet forest, 56 $49^{\prime} 6^{\prime \prime} \mathrm{N}, 2^{\circ} 50^{\prime} 18^{\prime \prime} \mathrm{E}$; D, conifer forest, 56 $53^{\prime} 4^{\prime \prime} \mathrm{N}, 24^{\circ} 26^{\prime} 32^{\prime \prime} \mathrm{E}$; E, peat bog, 56 $52^{\prime} 39^{\prime \prime} \mathrm{N}, 24^{\circ} 21^{\prime} 24^{\prime \prime} \mathrm{E}$ 
tanoides, Quercus robur, Ulmus laevis, and Tilia cordata on slopes of a river; habitat B was sparsely forested ravine with a stream and Ulmus laevis and Alnus incana on slopes; habitat C was a mixed wet forest with Picea abies, Quercus robur, Alnus glutinosa, and Betula pubescens; habitat D was conifer forest with Pinus sylvestris and Picea abies; habitat E was in the edges of a peat bog with Pinus sylvestris. In total, 25 of the common species growing on different substrates were chosen for the study (Table 1). Samples of each species were collected on a specific substrate except for Hypnum cupressiforme, which was found both on tree trunks and boulders and was designated as both epiphytic (species No. 6) and epilithic (No. 7). Bryophyte nomenclature follows the Plant List (Anonymous, 2013). Bryophyte life forms and life strategies were classified according to During (1979; 1992). Water conducting system was characterised according to Glime and references included in this source (Glime, 2007b).

Sampling. Bryophytes were sampled four times during summer (June 17, July 22, August 19, September 23) in order to eliminate any season-specific effects. Each sample consisted of about $20 \mathrm{~g}$ of bryophyte shoots taken from at least three different clumps, the samples were placed in sealed polyethylene bags and transported to the laboratory within $4 \mathrm{~h}$.

Water content analysis. To measure dry mass, bryophyte samples were weighed before and after drying in an oven at $70{ }^{\circ} \mathrm{C}$ for $72 \mathrm{~h}$. Field water content in samples was calculated as a fresh mass minus dry mass divided by dry mass and expressed as a percentage. For other water content traits, samples (about $5 \mathrm{~g}$ ) were weighed, immersed in distilled water for $1 \mathrm{~min}$, then taken out and allowed water to dry for $15 \mathrm{~s}$, then weighed again to determine fully hydrated water content. Samples were blotted with a four-folded paper towel for $15 \mathrm{~s}$ and weighed again to determine blotted tissue water content, which generally represents full-turgor water content (Proctor et al., 1998). The blotted samples were placed on a wet four-folded paper towel in a closed plastic container for $12 \mathrm{~h}$ in low light and then weighed to determine equilibrated water content. All estimates of water content were recalculated according to dry mass to determine relative water content. All water content measurements were performed in triplicate from the same sample.

Analysis of chlorophyll $\boldsymbol{a}$ fluorescence. Chlorophyll $a$ fluorescence was measured both in field and waterequilibrated samples in triplicate. Separate shoots from different clumps of the same sample were used. Field samples were analysed no later than $4 \mathrm{~h}$ after collection, while water-equilibrated samples were analysed after equilibration for $12 \mathrm{~h}$ in low light as described above. For each sample, five subsamples consisting of shoot apices were individually placed in standard leaf clips and left in the dark in sealed polyethylene bags for at least $20 \mathrm{~min}$. Fast fluorescence kinetics was measured with a continuous fluorometer Plant Efficiency Analyzer (Handy PEA; Hansatech Instruments, King's Lynn, UK). The results were analysed by PEA Plus software (Handy PEA; Hansatech Instruments,
King's Lynn, UK). Maximum quantum efficiency of PS II $\mathrm{F}_{\mathrm{v}} / \mathrm{F}_{\mathrm{m}}$, overall PS II activity $\left(\mathrm{F}_{\mathrm{v}} / \mathrm{F}_{0}\right)$, number of active PS II reaction centres with respect to absorbed light (RC/ABS), and overall energy conservation efficiency of the absorbed energy in PS II (Performance Index, PI) were used as estimates of PS II efficiency.

Measurement of photosynthetic pigments. Samples (about $5 \mathrm{~g}$ ) for pigment analysis were taken randomly from larger samples for each species and each month (Table 1), dried in low light at room temperature for one week and then stored in closed polyethylene bags at room temperature until analysis. These conditions led only to minimum changes in photosynthetic pigment concentration comparable to the variation between subsamples within the sample. Three subsamples (10 mg each) consisting of shoot apices were prepared from each sample. The tissues were ground with mortar and pestle in the presence of quartz sand and $\mathrm{CaCO}_{3}$ crystals, extracted with $10 \mathrm{ml} \mathrm{96 \%} \mathrm{ethanol} \mathrm{and} \mathrm{cen-}$ trifuged at $2000 \mathrm{~g}$ for $5 \mathrm{~min}$. Optical density of supernatants was measured at 440.5, 649 and $665 \mathrm{~nm}$ in triplicate. Pigment concentration was calculated according to the equations presented in published research (Wettstein, 1957; Wintermans and De Mots, 1965).

Data analysis. As the number of samples (bryophyte species) per functional group was small, principal component analysis (PCA) was performed first with 18 physiological traits for dimensionality reduction using the $\mathrm{R} 3.4 .1$ software (Anonymous, 2017). After PCA, functional group mean values of principal component 1 (PC1) and PC2 scores for functional types were compared using the Tukey-Kramer test. Physiological characteristics had four time points per species, each with three replicates.

To test for ability of 18 physiological traits (scaled variables) to discriminate functional types linear discriminant analysis (LDA) as implemented in package MASS (Venables and Ripley, 2002) of software R 3.4.1. (Anonymous, 2017) was used. Separate analyses were performed for functional types: (a) habitat with five groups, (b) substrate with five groups, (c) water conducting system with three groups, (d) life form with eleven groups, and (e) life strategy with seven groups. LDA was performed using leave-one-out cross-validation option to calculate mean posterior probability for each functional type group to be correctly predicted to known group.

\section{RESULTS}

Principal components analysis. Principal components analysis revealed the existence of an inverse relationship between concentration of photosynthetic pigments and water content traits (Fig. 1). Chlorophyll $a$ fluorescence traits $\mathrm{F}_{\mathrm{v}} / \mathrm{F}_{\mathrm{m}}$ and $\mathrm{F}_{\mathrm{v}} / \mathrm{F}_{0}$ in field bryophyte samples were most closely related to water content. Other fluorescence traits measured in field tissues, and particularly in waterequilibrated tissues, were not related to water content traits. To identify possible clustering by functional types, mean 


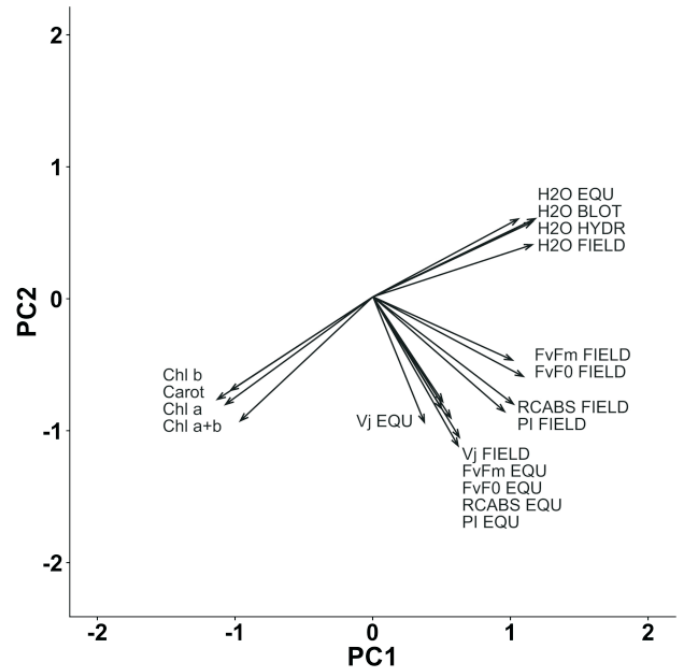

scores on PCA1 and PCA2 for bryophytes grouped by various functional types were plotted (Fig. 2). Significant differences between the species groups are given in Table 2. In
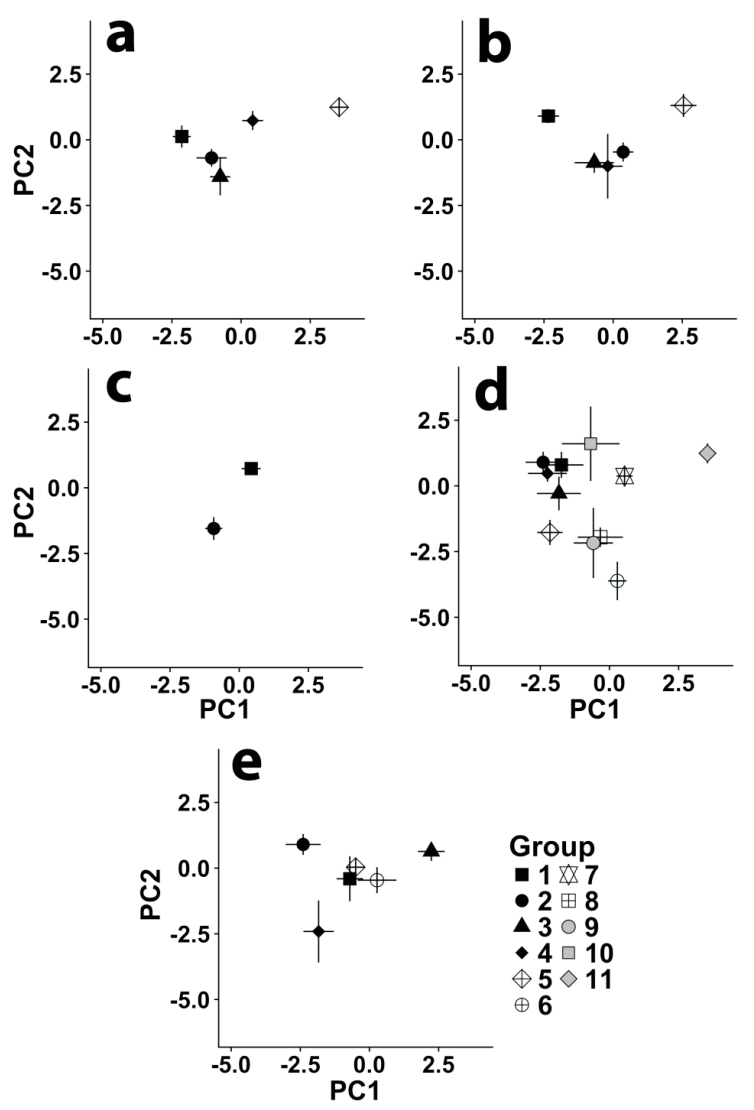

Fig. 2. Principal component analysis. Grouping of bryophyte species in principal component analysis according to functional types. (A) Habitat. 1: deciduous forest; 2 : ravine with stream; 3 : mixed wet forest; 4 : conifer forest; 5: peat bog. (B) Substrate. 1: epiphytic; 2: epigeic; 3: epilytic; 4: epixylic; 5: aquatic, semi-aquatic. (C) Water conducting system. 1: endohydric; 2: ectohydric non-Sphagnum; 3: ectohydric Sphagnum. (D) Life form. 1: rough mat; 2: smooth mat; 3: thalloid-mat; 4: thread-like mat; 5: tail; 6: small cushion; 7: dendroid; 8: short turf; 9: tall turf; 10: weft; 11: sphagnoid. (E) Life strategy. 1: pioneer; 2: stress-tolerant perennial; 3 : long-lived shuttle; 4: colonist; 5 : short-lived shuttle; 6 : competitive perennial; 7: perennial stayer. Mean scores \pm SE are shown. Significant differences between the species groups for the particular type are indicated in Table 2 . most habitats, except mixed wet forest, species had relatively variable fluorescence traits together with a somewhat fixed species-specific ratio between photosynthetic pigment concentration and water content (Fig. 2A). In mixed wet forest, the presence of two species with contrasting fluorescence traits, Atrichum undulatum and Lophocolea heterophylla, resulted in large variability for mean PC2 score. Along PC1, peat bog species significantly differed from other habitats (Table 2), and conifer forest species differed from species in deciduous forest and ravine habitats. Along PC2, peat bog species significantly differed from those growing in ravine and mixed wet forest habitats.

Species on different growth substrates showed some distinctive features with respect to water content/photosynthetic pigment concentrations (Fig. 2B). Epiphytic species formed a relatively discrete group based on a narrow pigment/water content ratio and relatively similar fluorescence traits, and the lowest photochemical activity among species. Epigeic, epilithic and epixylic species clustered together with no significant differences between them, while aquatic and semiaquatic species formed a distinct group that significantly differed from the other species in both PC1 and PC2 scores (except epiphytic species; Table 2).

Both ectohydric non-Sphagnum and endohydric species were similar in both photosynthesis- and water-related traits (Fig. 2C). However, ectohydric non-Sphagnum species had a low level of photochemical efficiency together with moderate pigment concentration and water content, while endohydric species had a relatively high level of both pigments and photochemical activity. Only endohydric species had both relatively high pigment concentration and relatively low water content together with high photochemical activity of PS II. Endohydric species significantly differed from ectohydric non-Sphagnum species (PC1 scores) and both endohydric and ectohydric non-Sphagnum species from ectohydric Sphagnum species (PC2 scores; Table 2).

Grouping of bryophyte species according to their life forms distinguished several clusters (Fig. 2D). Sphagnoid species (group 11) located far from the other groups, had high water 
Table 2. Significant differences in scores on first two axes between functional types of bryophyte species by principal coordinates analysis (Fig. 1)

\begin{tabular}{|c|c|c|c|}
\hline Group & & PC1 & $\mathrm{PC} 2$ \\
\hline \multicolumn{4}{|c|}{ Habitat } \\
\hline 1 & Deciduous forest & $\mathrm{c}$ & $a b c$ \\
\hline 2 & Ravine with stream & c & $\mathrm{bc}$ \\
\hline 3 & Mixed wet forest & $\mathrm{bc}$ & $\mathrm{c}$ \\
\hline 4 & Conifer forest & $\mathrm{b}$ & $a b$ \\
\hline 5 & Peat bog & a & $\mathrm{a}$ \\
\hline \multicolumn{4}{|c|}{ Substrate } \\
\hline 1 & Epiphytic & c & $a b$ \\
\hline 2 & Epigeic & $\mathrm{b}$ & $\mathrm{b}$ \\
\hline 3 & Epilithic & $\mathrm{bc}$ & $\mathrm{b}$ \\
\hline 4 & Epixylic & $\mathrm{bc}$ & $\mathrm{b}$ \\
\hline 5 & Aquatic, semi-aquatic & $\mathrm{a}$ & $\mathrm{a}$ \\
\hline \multicolumn{4}{|c|}{ Water conducting system } \\
\hline 1 & Endohydric & $\mathrm{b}$ & a \\
\hline 2 & Ectohydric, Sphagnum & $\mathrm{b}$ & $\mathrm{b}$ \\
\hline 3 & Ectohydric, non-Sphagnum & $\mathrm{a}$ & $\mathrm{a}$ \\
\hline \multicolumn{4}{|c|}{ Life form } \\
\hline 1 & Rough mat & $\mathrm{bc}$ & $a b c$ \\
\hline 2 & Smooth mat & c & $\mathrm{ab}$ \\
\hline 3 & Thalloid-mat & $\mathrm{bc}$ & abc \\
\hline 4 & Thread-like mat & $\mathrm{c}$ & abc \\
\hline 5 & Tail & $\mathrm{c}$ & $\mathrm{abc}$ \\
\hline 6 & Small cushion & $\mathrm{bc}$ & $\mathrm{abc}$ \\
\hline 7 & Dendroid & $\mathrm{b}$ & abc \\
\hline 8 & Short turf & $\mathrm{bc}$ & $\mathrm{abc}$ \\
\hline 9 & Tall turf & $\mathrm{bc}$ & ac \\
\hline 10 & Weft & $\mathrm{bc}$ & $\mathrm{a}$ \\
\hline 11 & Sphagnoid & a & a \\
\hline \multicolumn{4}{|c|}{ Life strategy } \\
\hline 1 & Pioneer & $\mathrm{bc}$ & $\mathrm{a}$ \\
\hline 2 & Stress-tolerant perennial & $\mathrm{bc}$ & $\mathrm{a}$ \\
\hline 3 & Long-lived shuttle & a & $\mathrm{a}$ \\
\hline 4 & Colonist & $\mathrm{bc}$ & $\mathrm{a}$ \\
\hline 5 & Short lived shuttle & $\mathrm{bc}$ & $\mathrm{b}$ \\
\hline 6 & Competitive perennial & $\mathrm{bc}$ & $\mathrm{a}$ \\
\hline 7 & Perennial stayer & $a b$ & $\mathrm{a}$ \\
\hline
\end{tabular}

Functional types indicated with the same letter within the particular group are not significantly different $(p>0.01)$

content together with low photosynthetic pigment concentration and variable intensity of fluorescence traits, and significantly differed from mean PC1 scores of other groups (Table 2). Another well-differentiating cluster was dendroid species (group 7). Species in the opposite corner of the ordination had low water content and high pigment concentration together with high values of fluorescence intensity traits. These species included tail (group 5) and small cushion (group 6) species, with short turf (group 8) and tall turf (group 9) species located closely. A cluster composed of rough mat (group 1), smooth mat (group 2), thalloid-mat (group 3) and thread-like mat (group 4) species had similar water content/pigment concentration ratio together with relatively low fluorescence intensity traits. Weft species (group 10) had relatively variable traits.

Ordination according to the life strategies (Fig. 2E) identified Atrichum undulatum (group 5), the only species with the short-lived shuttle strategy, in the lower left corner, and long-lived shuttle species in the far right upper corner. A distinct cluster with low water content/pigment ratio and low fluorescence intensity traits consisted of stress-tolerant perennial (group 2), colonist (group 4) and fugitive (group 8 ) species. Another cluster with more intermediate trait values consisted of pioneer (group 1), competitive perennial (group 6) and perennial stayer (group 7) species. Significant differences in scores were evident only between long-lived shuttle and the other species besides perennial stayer species (PC1 scores) as well as between short lived shuttle and all other species (PC2 scores).

Linear discriminant analysis. First and second linear discriminant accounted for 88.8 and $5.6 \%$ of total variation of different habitats (Fig. 3A). The most important physiological parameter for the first linear discriminant was field water content (2.615) and for the second it was field RC/ABS (1.878) and field $\mathrm{F}_{\mathrm{v}} / \mathrm{F}_{\mathrm{m}}(-1.394$; Table 3$)$. Only peat bog species had a higher field water content clearly separated by the first linear discriminant. Conifer forest species separated from other habitats by the second linear discriminant. Cross-validation showed that mean predicted posterior probabilities correctly classifying objects (species and species groups) according to physiological traits were $100 \%$ for peat bog species group, $58.2 \%$ for conifer forest group, $43.7 \%$ for deciduous forest group, $35.9 \%$ for ravine with stream group and $31.4 \%$ for mixed wet forest group.

LDA of substrate functional types showed that first linear discriminant explained 54.2 and second $20.6 \%$ of variation (Fig. 3B). Equilibrated PI (1.949), field water content (1.451) and blotted water content $(-1.392)$ were the most important parameters for the first linear discriminant, with field RC/ABS being the most important for the second $(-2.339$; Table 3$)$. Both epigeic and aquatic and semiaquatic species clearly separated from each other as well as from the rest of substrate groups according to the first discriminant. Epiphytic, epilithic and epixylic species separated according to the second discriminant. Highest mean posterior probability of correct classification was for epigeic group $(71.0 \%)$ and for aquatic, semi-aquatic group (67.3\%). Mean probability was $65.2 \%$ for epiphytic group, $52.5 \%$ for epilytic group and $49.9 \%$ for epixylic group.

First and second linear discriminant accounted for 92.3 and $7.7 \%$ of variation of water conducting system functional types (Fig. 3C). Field water content (2.478) was the most important parameter for the first linear discriminant, but equilibrated RC/ABS (2.225) and equilibrated PI (-2.091) were the most important for the second linear discriminant (Table 3). While ectohydric Sphagnum species with high field water content separated from the other two groups according to the first discriminant, endohydric and ectohydric non-Sphagnum species separated according to the second 

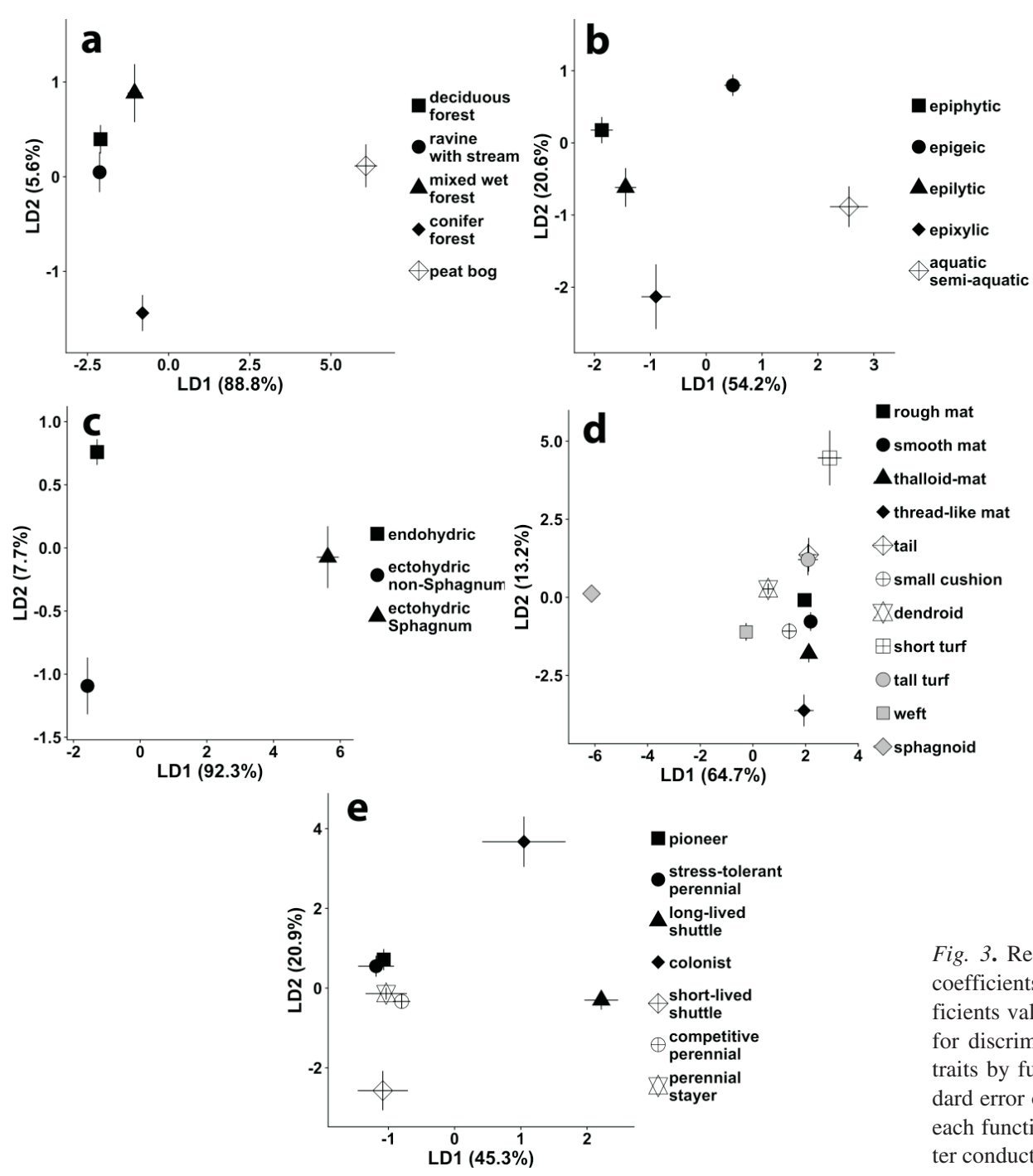

Fig. 3. Results of linear discriminant analysis showing coefficients of linear discriminants (higher absolute coefficients value shows higher importance of particular trait for discriminating functional types) of 18 physiological traits by functional type. Symbols show mean and standard error of the first and second linear discriminants for each function group. (A) Habitat. (B) Substrate. (C) Water conducting system. (D) Life form. (E) Life strategy.

discriminant. A $100 \%$ mean posterior probability of correct classification was for the ectohydric Sphagnum group, and it reached $76.7 \%$ for the endohydric group and $56.6 \%$ for the ectohydric non-Sphagnum group.

Life form function types LDA first and second linear discriminant accounted for 64.7 and $13.2 \%$ of variation (Fig. 3D). The most important physiological parameter for the first linear discriminant was field water content $(-2.146)$, and for the second discriminant it was chlorophyll $a+b$ concentration (1.970), but the number of other physiological parameters (chlorophyll $b$ concentration, field RC/ABS, chlorophyll $a$ concentration, field $\mathrm{F}_{\mathrm{v}} / \mathrm{F}_{\mathrm{m}}$, equilibrated $\mathrm{PI}$ ) also had relatively high impact (Table 3 ). Tail, tall turf, rough mat, smooth mat, thalloid-mat and thread-like mat species showed no separation according to the first discriminant, but differences in photosynthetic pigment concentrations allowed separation according to the second discriminant. Classification of life forms according to physiological traits was clearly life form-specific, as $100 \%$ mean posterior probability of correct classification was for the sphagnoid group but for the weft group there were no correct classification cases and only $1.6 \%$ for the rough mat group, but $17.0 \%$ for the tall turf group and $18.7 \%$ for the thalloid-mat group. For other groups mean posterior probabilities were between 35.5 and $76.5 \%$.

First and second linear discriminant accounted for $45.3 \%$ and $20.9 \%$ of variation of life strategy functional types (Fig. $3 E)$. Field $F_{v} / F_{m}(-2.786)$ and field RC/ABS (2.030) were the most important parameters for the first linear discriminant, and field PI (-1.818) was the most important for the second (Table 3). Long-lived shuttle and colonist species separated from the rest of life strategy groups according to the first discriminant. Colonist, and short-lived shuttle species separated from each other as well as from the rest of life strategy groups according to the second discriminant. However, a group consisting of pioneer, stress-tolerant perennial, perennial stayer and competitive perennial species showed almost no separation according to either discriminant. Mean posterior probabilities of correct classifications were $28.3 \%$ for pioneer group, $43.5 \%$ for stress-tolerant perennial group, $66.7 \%$ for long-lived shuttle group, $73.7 \%$ for colonist group, $25.5 \%$ for short-lived shuttle group, $51.7 \%$ for competitive perennial group, and $25.2 \%$ for perennial stayer group.

Comparison between the mean absolute values of coefficients for different physiological parameters revealed that 
Table 3. Results of linear discriminant analysis showing coefficients of linear discriminants (higher absolute coefficients value shows higher importance of particular trait for discriminating functional types) of 18 physiological traits by functional type

\begin{tabular}{|c|c|c|c|c|c|c|c|c|c|c|c|}
\hline \multirow[t]{2}{*}{ Trait } & \multicolumn{2}{|c|}{ Habitat } & \multicolumn{2}{|c|}{ Substrate } & \multicolumn{2}{|c|}{$\begin{array}{c}\begin{array}{c}\text { Water conducting } \\
\text { system }\end{array} \\
\end{array}$} & \multicolumn{2}{|c|}{ Life form } & \multicolumn{2}{|c|}{ Life strategy } & \multirow{2}{*}{$\begin{array}{c}\text { Mean } \\
\text { absolute } \\
\text { values }\end{array}$} \\
\hline & LD1 & LD2 & LD1 & LD2 & LD1 & LD2 & LD1 & LD2 & LD1 & $\mathrm{LD} 2$ & \\
\hline Water content, field & 2.615 & 0.561 & 1.451 & -0.235 & 2.478 & -0.963 & -2.146 & 0.682 & 1.562 & -0.232 & 1.29 \\
\hline $\begin{array}{l}\text { Water content, fully } \\
\text { hydrated }\end{array}$ & 0.724 & -0.127 & 0.924 & 0.147 & 0.438 & 0.180 & -1.126 & -0.106 & -0.296 & -0.527 & 0.46 \\
\hline Water content, blotted & -0.779 & -0.129 & -1.392 & 0.679 & -0.543 & -0.636 & 1.016 & -0.182 & 0.257 & -0.119 & 0.57 \\
\hline $\begin{array}{l}\text { Water content, } \\
\text { equilibrated }\end{array}$ & 0.776 & 0.113 & 0.657 & -0.352 & 0.742 & 0.896 & -0.787 & 0.041 & 0.256 & 0.448 & 0.51 \\
\hline $\mathrm{F}_{\mathrm{v}} / \mathrm{F}_{\mathrm{m}}$, field & -0.393 & -1.394 & 0.638 & -1.368 & -1.332 & -0.153 & 0.793 & 1.447 & -2.786 & -1.207 & 1.15 \\
\hline $\mathrm{F}_{\mathrm{v}} / \mathrm{F}_{\mathrm{m}}$, equilibrated & 0.528 & -0.105 & 0.832 & 0.524 & 0.446 & -0.062 & -0.151 & -0.436 & 0.390 & 0.916 & 0.44 \\
\hline RC/ABS, field & 0.723 & 1.878 & -0.199 & 0.664 & 1.295 & -0.301 & -1.141 & -1.485 & 2.030 & 0.923 & 1.06 \\
\hline RC/ABS, equilibrated & -0.919 & 0.4691 & -1.236 & -2.339 & -0.489 & 2.225 & -0.149 & -1.166 & -1.997 & 0.070 & 1.11 \\
\hline $\mathrm{F}_{\mathrm{v}} / \mathrm{F}_{0}$, field & -1.088 & 0.308 & -0.191 & 1.420 & -0.288 & 0.181 & 0.758 & -0.368 & 1.531 & 1.160 & 0.73 \\
\hline $\mathrm{F}_{\mathrm{v}} / \mathrm{F}_{0}$, equilibrated & -0.593 & -0.518 & -1.026 & 0.252 & -0.512 & 0.100 & 0.202 & 0.549 & -0.334 & -1.026 & 0.51 \\
\hline$\left(1-V_{j}\right) / V_{j}$, field & -0.285 & 0.268 & 0.078 & -0.380 & -0.370 & -0.556 & 0.247 & -0.502 & 0.316 & 0.836 & 0.39 \\
\hline$\left(1-V_{j}\right) / V_{j}$, equilibrated & -0.336 & -0.009 & -1.035 & -0.048 & -0.103 & 0.102 & 0.220 & -0.423 & 0.494 & 0.969 & 0.37 \\
\hline PI, field & 1.103 & -1.051 & 0.138 & -0.776 & 0.440 & 0.036 & -0.661 & 1.145 & -1.609 & -1.818 & 0.88 \\
\hline PI, equilibrated & 0.946 & -0.205 & 1.949 & 1.711 & 0.357 & -2.091 & 0.182 & 1.341 & 1.408 & -1.016 & 1.12 \\
\hline Chl $a$ & -1.156 & 0.096 & 0.142 & -0.710 & -0.845 & 1.090 & 0.844 & 1.455 & -0.241 & -0.456 & 0.70 \\
\hline Chl $b$ & 0.890 & -0.030 & -0.165 & -0.273 & 0.752 & 0.347 & -1.110 & -1.541 & -0.103 & 0.676 & 0.59 \\
\hline Chl $a+b$ & -0.110 & 1.131 & 0.901 & 0.614 & 0.011 & -0.845 & 0.309 & 1.970 & 0.889 & -0.591 & 0.74 \\
\hline Carotenoids & 0.343 & -0.345 & -0.445 & 0.818 & 0.062 & -1.474 & 0.361 & -1.247 & -0.619 & -0.225 & 0.60 \\
\hline
\end{tabular}

field water content had the highest average discriminative importance (1.29), followed by field $\mathrm{F}_{\mathrm{v}} / \mathrm{F}_{\mathrm{m}}(1.15)$, equilibrated PI (1.12), equilibrated RC/ABS (1.11), and field RC/ABS (1.06; Table 2). Photosynthetic pigment concentrations had relatively less average importance.

\section{DISCUSSION}

From a practical point of view, it is usually assumed that functional groups of bryophytes differentially respond to climate changes and biogeographic effects (Baldwin and Bradfield, 2007). For example, it is often stressed that bryophyte life forms are adaptations to low water availability, particular light intensity, and physical characteristics of a substrate (Bates, 1998).

The present study focused on several quantitatively assessed traits related to tissue water content and photosynthesis (concentration of chlorophylls and carotenoids, as well as chlorophyll $a$ fluorescence) as possible indicators for functional classification purposes. It was hypothesised that these characteristics could be used to discriminate between different groups of species (functional types) within different systems of functional classification. The study showed that the examined traits differed in their ability to predict functional types.

As expected, water-content traits differed between species groups differing in water conducting system characteristics. Field water content had the highest average discriminative importance for classification of different functional types, especially for habitat, water conducting system and life form, followed by life strategy and substrate (Table 2).

While field tissue water content (hydration state) is directly dependent on water availability in the microenvironment as well as physical characteristics of a substrate (Glime, 2007a), the ability to accumulate water seems to be a species-specific characteristic, at least, to some extent. Both Sphagnum and non-Sphagnum aquatic and semi-aquatic species had statistically significant higher field and fully hydrated tissue water content in comparison to other species. It appears that physical capacity to hold water is related to specific morphological features of bryophyte shoots. The presence of large hyaline cells within a layer of leaf cells in Sphagnum species is an adaptation for holding a relatively high water content extracellularly (Andrus, 1986). Even within closely related Sphagnum species, some may have better ability to hold water, e.g., Sphagnum magellanicum, a hummock species, in comparison to other species (Li et al., 1992). Other structural adaptations at the leaf morphology level (concave, multi-layered and overlapping leaves, specialised structures) can provide higher ability to absorb (Proctor, 1979). It should be noted also that extremely high relative water content in bryophyte tissues (above 1000\%) can lead to decrease in $\mathrm{CO}_{2}$ fixation rate, as noted for Sphagnum species (Silvola and Aaltonen, 1984). The value over $1000 \%$ was exceeded also in the present study in Sphagnum species in field state (with an average value for all Sphagnum species $1156 \pm 66$ ).

In a broader context, photosynthesis-related characteristics, including chlorophyll $a$ fluorescence, are widely used in 
ecophysiological studies of vascular plants both in relation to plant productivity and physiological vitality (ZarcoTejada et al., 2002). However, in bryophytes, fluorescence analysis has been used mostly for water availability studies (e.g., Proctor, 2003; Beckett et al., 2005; Cruz de Carvalho et al., 2011) and only relatively few studies have dealt with light effects (Murray et al., 1993; Ren et al., 2010; Proctor and Smirnoff, 2011). Relatively high photochemical activity of PS II is usually associated with a well-hydrated state of bryophyte tissues and vice versa (Davey, 1997). Surprisingly, in the present study, intensity of photochemical processes was only to a relatively low extent related to field water content. It is possible that, besides water status of tissues, other environmental factors contribute to changes in photochemical activity of PS II in bryophytes in field conditions, as fluorescence traits in water-equilibrated tissues showed no relationship with pigment concentration and climate variables. It is well known that light intensity directly positively affects both photochemical activity and rate of $\mathrm{CO}_{2}$ fixation, but many bryophyte species are adapted to low-light conditions (Rincòn, 1993). Consequently, low but stable intensity of photochemical activity and photosynthesis is expected in shaded conditions for most bryophyte species, while sudden increase in light availability for wellwatered bryophytes can result in photoinhibition of photosynthesis and growth inhibition (Murray et al., 1993). Therefore, decreased level of chlorophyll $a$ fluorescence traits in the present study might be an indication of high light intensity-related negative effects on photochemical activity of PS II.

In general, chlorophyll $a$ fluorescence indices were significantly better physiological traits for classification of functional types in comparison to photosynthetic pigment concentrations (Table 3). Only species with different life forms appeared to be significantly discriminated on the basis of chlorophyll $a$ and $b$ concentrations. However, general probabilities of correct classification of life forms according to physiological traits were highly variable for different life forms, ranging from $0 \%$ in the case of weft and $1.6 \%$ of rough mat species to $100 \%$ for sphagnoid species, with mean value of $35.6 \%$.

Relatively similar pigment/water content ratio of bryophyte species within functional groups is interesting, but physiological basis of species-specific water content/pigment concentration ratio is not clear. Is it possible that chlorophyll concentration is regulated by water content? In an artificial experimental system consisting of a water gradient, tests with five bryophyte species showed that both chlorophyll $a$ and chlorophyll $b$ concentrations increased with increasing tissue water content (Spitale, 2009), which contradicts the present results. Also, higher chlorophyll concentration has been found in aquatic species than in terrestrial bryophytes (Lopez and Carballeira, 1989). In the study of Spitale (2009) moss samples were acclimated to particular conditions for 20 days, and therefore the described relationship might be attributed to physiological response of the bryophyte species to the hydration level. In the present study, in- stead of short-term or long-term response of photosynthetic pigment concentration of the particular species to changes in tissue water content, the pigment/water relationship was assessed on a broader scale using a range of bryophyte species in relatively homogeneous field conditions of boreonemoral habitats most likely reflecting long-term physiological adaptations to the prevailing set of environmental conditions.

It is likely that the amount of light available to bryophyte at a particular time, in relation to interaction between natural light and microhabitat conditions, can affect its photosynthetic pigment concentration. It has been shown that decrease in ambient light intensity results in increased chlorophyll content for bryophytes (Sluka, 1983). It is interesting to note that in bryophytes carotenoids can function not only in dissipation of excess energy (Britton, 1995; Heber et al., 2006) but also as accessory pigments in antenna complexes complexes (Czeczuga, 1985). Other environmental variables not estimated in the present study within the habitats generally were similar as they were located not further than $35 \mathrm{~km}$ apart. However, microenvironmental heterogeneity associated with substrate topography might be important.

It seems that functional classification systems only partially and to a various extent reflect particular morphological and physiological adaptations. According to the life strategy classification system, all Sphagnum species represent the long-lived shuttle type. This type was represented also by epiphytic Leucodon sciuroides and Conocephalum conicum, the only liverwort species in the present study. It is wellestablished fact Sphagnum species need higher tissue water content to maintain optimum photosynthesis, in comparison to other bryophyte species (Silvola and Aaltonen, 1984). Another well-discriminated species group in our study had a high photosynthetic pigment concentration/water content ratio as well as high photochemical activity of PS II as indicated by chlorophyll $a$ fluorescence traits. This particular group consisted of four species, Plagiomnium undulatum, Conocephalum conicum, Tetraphis pellucida and Atrichum undulatum. All of them are endohydric, possessing an internal water-conducting system. Atrichum undulatum, the species showing the highest concentration of photosynthetic pigments together with a high intensity of fluorescence traits, is known to have high intensity of photosynthetic $\mathrm{CO}_{2}$ fixation in respect to unit of surface (Krupa, 1984). This physiological feature is associated with a ventilated photosynthesis system due to lamellar structure of leaves. It can be suggested that all members of this group have a similar type of morphological adaptation allowing for efficient photosynthesis at low but relatively stable tissue water content.

One might argue that the distribution of species within the defined continuum of tissue water content, pigment concentration and chlorophyll $a$ fluorescence traits may have a stochastic character. Variability of characteristics within particular species was indeed relatively high, as it was already noted in a previous study (Liepiņa and Ievinsh, 2013). It was attempted to eliminate any seasonal dependence of the 
measured traits by sampling the same bryophyte species four times during summer. Therefore, a single species was represented by a relatively higher variation within a continuum of water content, photosynthetic pigment and chlorophyll $a$ fluorescence traits. Seasonal differences in physiological traits, while well known (e.g. Kershaw and Webber, 1986), are often a neglected aspect in ecophysiological analysis of bryophytes. Sampling of different species only at particular times during the season can potentially result in a significant season-specific component of established relationships. Regarding other potential limitations of the present study, it is necessary to stress out that the particular method used for analysis of relationships between functional traits among functional types of bryophytes can greatly affect the outcome of the analysis. Thus, LDA resulted in a better ability to discriminate between substrates, life forms and life strategies in comparison to PCA, but for habitat and water conducting system the ability was relatively similar. It is generally believed that LDA is a far better method of classification analysis maximizing class separation, but it was also argued that PCA can outperform LDA if the number of samples is relatively small (Martinez and Kak, 2001), which was the case also in the present study. Consequently, PCA in the present study gave more ecophysiologically relevant information, showing relationships between various traits for species from different functional groups, while LDA allowed for use of physiological traits in bryophyte functional classification.

\section{CONCLUSIONS}

Individual bryophyte species had a clearly distinctive position within the multifactor gradient of tissue water content vs. photosynthetic pigment concentrations and high/low photochemical activity of PS II. The complex use of quantitatively measured functional traits by principal component analysis and linear discriminant analysis allowed to discriminate between functional types of bryophytes within different systems of functional classifications. Inverse relationship between concentration of pigments and water content was found, in general showing that species with higher water storage ability had lower photosythetic capacity at the level of particular pigment content. Field water content and chlorophyll fluorescence indices field $\mathrm{F}_{\mathrm{v}} / \mathrm{F}_{\mathrm{m}}$, equilibrated $\mathrm{PI}$, equilibrated RC/ABS, and field RC/ABS were important functional traits for characterisation of water conducting system, substrate and habitat, and, to a lesser extent, life strategy, while chlorophyll $a$ and $b$ concentrations were important for discrimination of life form, being highest in dendroid and lowest in sphagnoid species. These particular traits had the highest discriminatory ability within the studied systems of functional classification.

\section{ACKNOWLEDGEMENTS}

The present study was in part supported by an infrastructure grant No. 2012/0001/2DP/2.1.1.3.1/11/IPIA/VIAA/005. Help of Dr. biol. Lelde Grantina-Ievinga on initial statistical analysis and Prof. Guntis Brūmelis on language correction is highly appreciated.

\section{REFERENCES}

Albert, K. R., Mikkelsen, T. N., Ro-Poulsen, H., Arndal, M. F., Michelsen, A. (2011). Ambient UV-B radiation reduces PSII performance and net photosynthesis in high Arctic Salix arctica. Environ. Exp. Bot., 73, 10-18.

Andrus, R. E. (1986). Some aspects of Sphagnum ecology. Can. J. Bot., 64, $416-426$.

Anonymous (2013). The Plant List Version 1.1. http://www.theplantlist.org/ (accessed 4 September 2017).

Anonymous (2017). R: A language and environment for statistical computing. R Foundation for Statistical Computing, Vienna, Austria. http://www.R-project.org (accessed 15 August 2017).

Baker, N. R. (2008). Chlorophyll fluorescence: A probe of photosynthesis in vivo. Annu. Rev. Plant Biol., 59, 89-113.

Baldwin, I. K., Bradfield, G. E. (2007). Bryophyte responses to fragmentation in temperate coastal rainforests: A functional group approach. Biol. Conserv., 136, 408-422.

Bates, J. W. (1998). Is 'life-form' a useful concept in bryophyte ecology? Oikos, 82, 223-237.

Beckett, R. P., Marschall M., Laufer Z. (2005). Hardening enhances photoprotection in the moss Atricum androgynum during rehydration by increasing fast- rather than slow-relaxing quenching. J. Bryol., 27, 7-12.

Britton, G. (1995). Structure and properties of carotenoids in relation to function. FASEB J., 9, 1551-1558.

Cruz de Carvalho, R., Branquinho, C., Marques da Silva, J. (2011). Physiological consequences of desiccation in the aquatic bryophyte Fontinalis antipyretica. Planta, 234, 195-205.

Czeczuga, B. (1980). Investigation on carotenoids in Embryophyta. I. Bryophyta. Bryologist, 83, 21-28.

Davey, M. C. (1997). Effects of short-term dehydration and rehydration on photosynthesis and respiration by Antarctic bryophytes. Environ. Exp. Bot., 37, 187-198.

Dray, S., Dufour, A. B. (2007). The ade4 package: implementing the duality diagram for ecologists. J. Stat. Softw., 22, 1-20.

During, H. J. (1979). Life strategies of bryophytes: A preliminary review. Lindbergia, 5, 2-18.

During, H. J. (1992). Ecological classifications of bryophytes and lichens. In: Bates, J. W., Farmer, A. M. (eds.). Bryophytes and Lichens in a Changing Environment. Clarendon Press, Oxford, pp. 1-31.

Gimingham, C. H., Birse, E. M. (1957). Ecological studies on growth-form in bryophytes: I. Correlations between growth-form and habitat. J. Ecol., 45, 533-545.

Glime, J. M. (2007a). Water relations: habitat. In: Glime, J. M. Bryophyte Ecology. Volume 1. Physiological Ecology. Chapt. 7-8. Ebook sponsored by Michigan Technological University and the International Association of Bryologists. http://www.bryoecol.mtu.edu/ (accessed 12 March 2017)

Glime, J. M. (2007b). Water relations: movement. In: Glime, J. M. Bryophyte Ecology. Volume 1. Physiological Ecology. Chapt. 7-2. Ebook sponsored by Michigan Technological University and the International Association of Bryologists. http://www.bryoecol.mtu.edu/ (accessed 12 March 2017).

Heber, U., Bilger, W., Shuvalov, V. A. (2006). Thermal energy dissipation in reaction centres and in the antenna of photosystem II protects desiccated poikilohydric mosses against photo-oxidation. J. Exp. Bot., 57, 2993-3006.

Kershaw, K. A., Webber, M. R. (1986). Seasonal changes in the chlorophyll content and quantum efficiency of the moss Brachythecium rutabulum. $J$. Bryol., 14, 151-158. 
Krupa, J. (1984). Anatomical structure of moss leaves and their photosynthetic activity. Acta Soc. Bot. Polon., 53, 43-51.

Kürschner, H. (2004). Life strategies and adaptations in bryophytes from the Near and Middle East. Turkish J. Bot., 28, 73-84.

Lavorel, S., Díaz, S., Cornelissen, H. C., Garnier, E., Harrison, S. P., McIntyre, S., Pausas, J. G., Pérez-Harguindeguy, N., Roumet, C., Urcelay, C. (2007). Plant functional types: are we getting any closer to the Holy Grail? In: Canadell, J. G., Pataki D. E., Pitelka, L. F. (eds.). Terrestrial Ecosystems in a Changing World. Springer-Verlag, Berlin-Heidelberg, pp. 149-164.

Li, Y., Glime, J. M., Liao, C. (1992). Responses of two interacting Sphagnum species to water level. J. Bryol., 17, 59-70.

Liepiņa, L., Ievinsh, G. (2013). Potential for fast chlorophyll $a$ fluorescence measurement in bryophyte ecophysiology. Estonian J. Ecol., 62, 137-149.

Lopez, J., Carballeira, A. (1989). A comparative study of pigment contents and response to stress in five species of aquatic bryophytes. Lindbergia, 15, 188-194.

Marschall, M., Proctor, M. C. F. (2004). Are bryophytes shade plants? Photosynthetic light responses and proportions of chlorophyll $a$, chlorophyll $b$ and total carotenoids. Ann. Bot., 94, 593-603.

Martin, C. E., Warner, D. A. (1984). The effects of desiccation on concentrations and $a / b$ ratios of chlorophyll in Leucobryum glaucum and Thuidium delicatulum. New Phytol., 96, 545-550.

Martinez, A. M., Kak, A. C. (2001). PCA versus LDA. IEEE Transact. Pattern Anal. Machine Intel., 23, 228-233.

Martínez-Abaigar, J., Núñez-Olivera, E., Sánchez-Díaz, M. (1994). Seasonal changes in photosynthetic pigment composition of aquatic bryophytes. J. Bryol., 18, 97-113.

Murchie, E. H., Lawson, T. (2013). Chlorophyll fluorescence analysis: A guide to good practice and understanding some new applications. J. Exp. Bot., 64, 3983-3998.

Murray, K. J., Tenhunen, J. D., Nowak, R. S. (1993). Photoinhibition as a control on photosynthesis and production of Sphagnum mosses. Oecologia, 96, 200-2007.

Proctor, M. C. F. (1979). Structure and eco-physiological adaptations in bryophytes. In: Clarke, G. S. C., Duckett, J. G. (eds.). Bryophyte Systematics. Academic Press, London, pp. 479-509.
Proctor, M. C. F. (2003). Experiments on the effect of different intensities of desiccation on bryophyte survival, using chlorophyll fluorescence as an index of recovery. J. Bryol., 25, 201-210.

Proctor, M. C. F., Nagy, Z., Csintalan, Z., Takács, Z. (1998). Water-content components in bryophytes: Analysis of pressure-volume relationships. $J$. Exp. Bot., 49, 1845-1854.

Proctor, M. C. F., Smirnoff, N. (2011). Ecophysiology of photosynthesis in bryophytes: Major roles for oxygen photoreduction and non-photochemical quenching? Physiol. Plant., 141, 130-140.

Ren, W., Tan, H., Wy, J., Deng, W., Wu, Y., Tang, Y., Cui, X. (2010). UV light spectral response of photosynthetic photochemical efficiency in alpine mosses. J. Plant Ecol., 3, 17-24.

Rincòn, E. (1993). Growth responses of six bryophyte species to different light intensities. Can. J. Bot., 71, 661-665.

Spitale, D. (2009). Spatial distribution of bryophytes along a moisture gradient: An approach using photosynthetic pigments as indicators of stress. Ecol. Res., 24, 1279-1286.

Silvola, J., Aaltonen, H. (1984). Water content and photosynthesis in the peat mosses Sphagnum fuscum and S. angustifolium. Ann. Bot. Fenn., 21, 1-6.

Sluka, Z. A. (1983). The dependence of the chlorophyll content and the leaf-area of mosses on the ecological conditions. Vestnik Moskovskogo Universiteta Ser. XVI Biologija, 37, 24-29.

Strazdin,a, L., Brūmelis, G., Rēriha, I.( 2013). Life-form adaptations and substrate availability explain a 100-year post-grazing succession of bryophyte species in Moricsala Strict Nature Reserve, Latvia. J. Bryol., 35, 33-46.

Venables, W. N., Ripley, B. D. (2002). Modern Applied Statistics with S. Springer, New York. 498 pp.

Vieira, C., Séneca, A., Sérgio, C., Ferreira, M. T. (2012). Bryophyte taxonomic and functional groups as indicators of fine scale ecological gradients in mountain streams. Ecol. Indic., 18, 98-107.

Wettstein, D. (1957). Chlorophyll-letale und der Submikroskopische Formwechsel der Plastiden. Exp. Cell Res., 12, 427-506.

Wintermans, J. F. G. M., De Mots, A. (1965). Spectrophotometric characteristics of chlorophyll $a$ and $b$ and their pheophytins in ethanol. Biochim. Biophys. Acta, 109, 448-453.

Zarco-Tejada, P. J., Miller, J. R., Mohammed, G. H., Noland, T. L., Sampson, P. H. (2002). Vegetation stress detection through chlorophyll a + b estimation and fluorescence effects on hyperspectral imagery. J. Env. Qual., 31, 1433-1441.

Received 21 November 2018

Accepted in the final form 12 June 2019

\section{SAISTİBA STARP FUNKCIONĀLAJĀM İPAŠĪBĀM, FUNKCIONĀLAJIEM TIPIEM UN BIOTOPU BOREONEMORĀLAJIEM SŪNAUGIEM}

Pētījuma mērḳis bija noteikt sakarību starp fizioloğiskajām īpašībām un funkcionālajiem tipiem briofìtiem no pieciem boreonemorālajiem biotopiem, īpašu uzmanību pievēršot šo īpašǐbu izškiršanas spējai. Paraugus no 25 sūnaugu sugām ievāca četras reizes vienas veǵetācijas sezonas laikā. Gan lauka paraugos, gan paraugos ar līdzsvarotu ūdens saturu noteica ūdens daudzumu, hlorofila $a$ fluorescenci un fotosintēzes pigmentu koncentrāciju. Principiālo komponentu analīze atklāja apgrieztu saistību starp pigmentu koncentrāciju un ūdens saturu. Lineāro diskriminantu analīze parādīja, ka salīdzinoši augsta vidējā sekojošās varbūtības klasifikācijas iespēja pēc fizioloğiskajām īpašībām ir ūdens vadīšanas sistēmai, bet mazākā mērā substrātam un biotopam, taču šì iespēja bija lioti variabla un tipa specifiska dzīvības formām, bet mazāk variabla dzīvības stratēg̣ijām. Lauka ūdens saturam bija augstākā vidējā izškiršanas nozīme no visām fizioloğiskajām īpašībām, tam sekoja hlorofila fluorescences parametri lauka $\mathrm{F}_{\mathrm{v}} / \mathrm{F}_{\mathrm{m}}$, izlīdzinātais PI, izlīdzinātais RC/ABS un lauka RC/ABS. Fotosintēzes pigmentu koncentrācijai bija salīdzinoši maza nozīme funkcionālo tipu klasifikācijā. 